\title{
Accessing Pincer Bis(carbene) Ni(IV) Complexes from Ni(II) via Halogen and Halogen Surrogates
}

\author{
Gabriel Espinosa Martinez, Cristian Ocampo, Yun Ji Park, and Alison R. Fout. \\ Department of Chemistry, University of Illinois at Urbana-Champaign. \\ 600 S. Mathews Ave. Urbana, IL 61801.
}

\section{Supporting Information Table of Contents:}

General Considerations

$\mathrm{S} 2$

Figure S1. Cyclic voltammogram of $\left({ }^{\mathrm{DIPP}} \mathrm{CCC}\right) \mathrm{NiCl}$

(1).

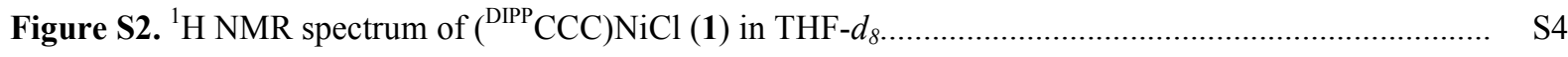

Synthesis of $\left({ }^{\mathrm{DIPP}} \mathrm{CCC}\right) \mathrm{NiCl}_{3}$

(2).

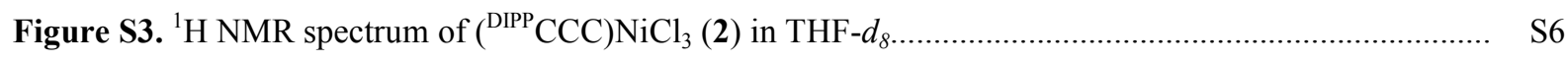

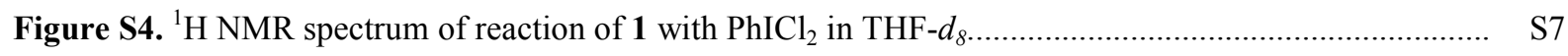

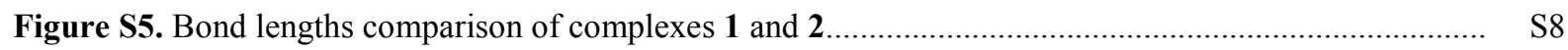

Synthesis of $\left({ }^{\mathrm{DIPP}} \mathrm{CCC}\right) \mathrm{NiBr}$

(3).

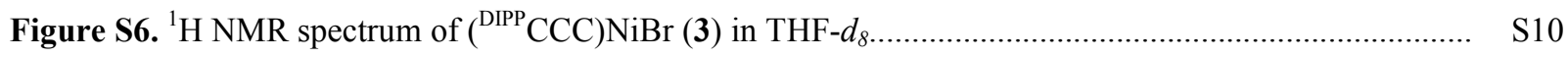

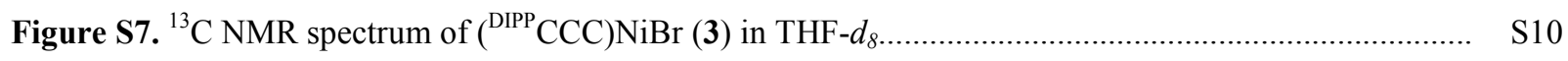

Figure S8. ${ }^{1} \mathrm{H}$ NMR spectrum of $\left({ }^{\mathrm{DIPP}} \mathrm{CCC}\right) \mathrm{NiBr}(\mathbf{3})$ in benzene- $\quad$ S11

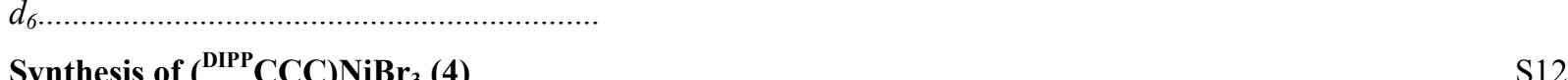

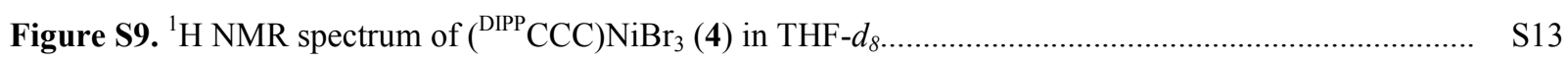

Figure S10. ${ }^{13} \mathrm{C}$ NMR spectrum of $\left({ }^{\mathrm{DIPP}} \mathrm{CCC}\right) \mathrm{NiBr}_{3}(4)$ in THF- $\quad \mathrm{S} 13$

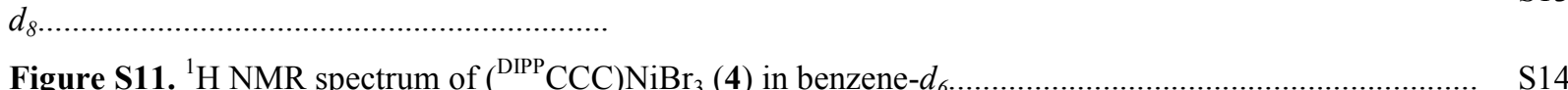

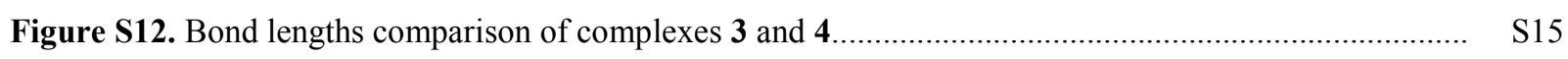

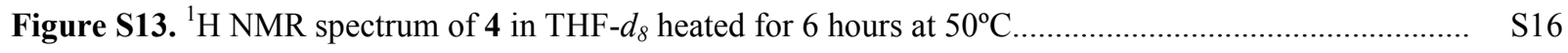

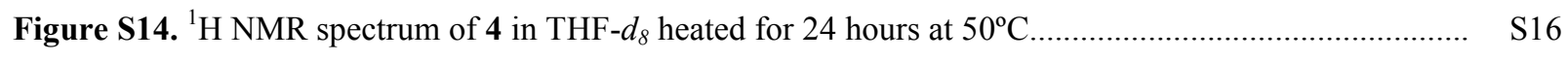

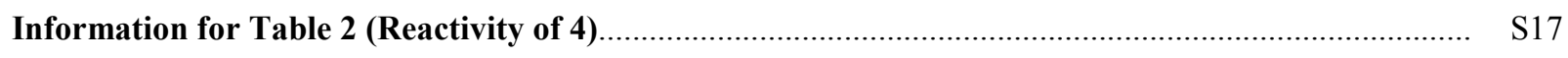

Figure S15. ${ }^{1} \mathrm{H}$ NMR Spectrum of reaction 4 with styrene in THF- $d_{8}(\delta 3.58,1.73) \ldots \ldots \ldots \ldots \ldots \ldots \ldots \ldots \ldots$

Figure S16. ${ }^{1} \mathrm{H}$ NMR Spectrum of reaction 4 with cyclohexene in $\mathrm{THF}-d_{8}(\delta 3.58,1.73) \ldots \ldots \ldots \ldots \ldots \ldots \ldots \ldots$

Figure S17. ${ }^{1} \mathrm{H}$ NMR Spectrum of reaction 4 with cyclohexene in $\mathrm{THF}-d_{8}(\delta 3.58,1.73) \ldots \ldots \ldots \ldots \ldots \ldots \ldots \ldots$ 
Figure S18. ${ }^{1} \mathrm{H}$ NMR Spectrum of reaction 4 with 2 -mesitylmagnesium bromide (1 eq.) in benzene- $d_{6}(\delta$ 7.16)

Figure S19. ${ }^{1} \mathrm{H}$ NMR Spectrum of reaction 4 with $\mathrm{TMS}_{2} \mathrm{NLi}(1$ eq. $)$ in benzene- $d_{6}(\delta 7.16)$.

Table S1. Crystallographic parameters for complexes 2-4.

General Considerations. All air and moisture-sensitive manipulations were performed using an MBraun inert atmosphere drybox with an atmosphere of nitrogen. The MBraun drybox was equipped with two $-35^{\circ} \mathrm{C}$ freezers for cooling samples and crystallizations. Solvents for sensitive manipulations were dried and deoxygenated on a Glass Contour System (SG Water USA, Nashua, NH) and stored over $4 \AA$ molecular sieves purchased from Strem following literature procedure prior to use. ${ }^{1}\left({ }^{\mathrm{DIPP}} \mathrm{CCC}\right) \mathrm{NiCl}^{2}$ and iodobenzene dichloride $\left(\mathrm{PhICl}_{2}\right)^{3}$ were prepared as previously reported. Sodium thiophenolate (technical grade, 90\%), bromine, styrene, cyclohexene, 2-mesitylmagnesium bromide $1.0 \mathrm{M}$ in THF, and 2,4,6triisopropylphenylmagnesium bromide $0.5 \mathrm{M}$ in THF were purchased from Sigma-Aldrich and used as received. Benzyltrimethylammonium tribromide was purchased from Oakwood Chemical and used as received. Lithium hexamethyldisilazide was purchased from SigmaAldrich and recrystallized from toluene under inert atmosphere before use. 1,2dibromocyclohexane was prepared according to literature procedures. ${ }^{4}$ NMR solvent (THF- $d_{8}$, benzene- $d_{6}$ ) were purchased from Cambridge Isotope Laboratories, degassed, and dried with $4 \AA$ molecular sieves.

${ }^{1} \mathrm{H}$ and ${ }^{13} \mathrm{C}$ NMR spectra were recorded on a Varian spectrometer operating at $400 \mathrm{MHz}$ and $500 \mathrm{MHz}\left({ }^{1} \mathrm{H}\right.$ NMR), and $100 \mathrm{MHz}$ and $126 \mathrm{MHz}\left({ }^{13} \mathrm{C} \mathrm{NMR}\right)$ at ambient temperature. All chemical shifts were reported relative to the peak of the residual solvent as a standard (THF- $d_{8}$ : ${ }^{1} \mathrm{H}$ NMR $\delta 3.58,1.73$; $13 \mathrm{C}$ NMR $\delta 67.21,25.1$; benzene- $d_{6}:{ }^{1} \mathrm{H}$ NMR $\delta$ 7.16). Electrochemical experiments were carried out using a $\mathrm{CH}$ Instruments CHI410C Electrochemical Workstation. The supporting electrolyte was $0.1 \mathrm{M}\left[{ }^{\mathrm{n}} \mathrm{Bu}_{4} \mathrm{~N}\right]\left[\mathrm{PF}_{6}\right]$ in dichloromethane. Cyclic voltammetry was performed with a scan rate of $100 \mathrm{mV} / \mathrm{s}$. Each scan was referenced to an external $\mathrm{Fc} / \mathrm{Fc}^{+}$couple for a ferrocene sample analyzed under identical conditions. Mass Spectrometry analyses were performed by the University of Illinois at Urbana-Champaign Mass Spectrometry Laboratory. Elemental analyses were performed by the University of Illinois at Urbana-Champaign School of Chemical Sciences Microanalysis Laboratory in Urbana, IL. X-ray analyses were performed at the George L. Clark X-Ray Facility and 3M Material Laboratory at the University of Illinois at Urbana-Champaign, using a Bruker D8 Venture Duo or Bruker X8ApexII diffractometer. 
Analysis by Gas Chromatography Mass Spectrometry (GC-MS) was performed using a Shimadzu GC-2010 Plus Gas Chromatograph equipped with a Shimadzu GCMS-QP2010 SE mass spectrometer using electron impact ionization (EI) after traveling through a SH-Rxi ${ }^{\mathrm{TM}}-5 \mathrm{~ms}$ $30 \mathrm{~m} \times 0.32 \mathrm{~mm} \times 0.25 \mu \mathrm{m}$ column with helium carrier gas.

Figure S1. Cyclic voltammogram of $\left({ }^{\mathrm{DIPP}} \mathrm{CCC}\right) \mathrm{NiCl}(\mathbf{1})$

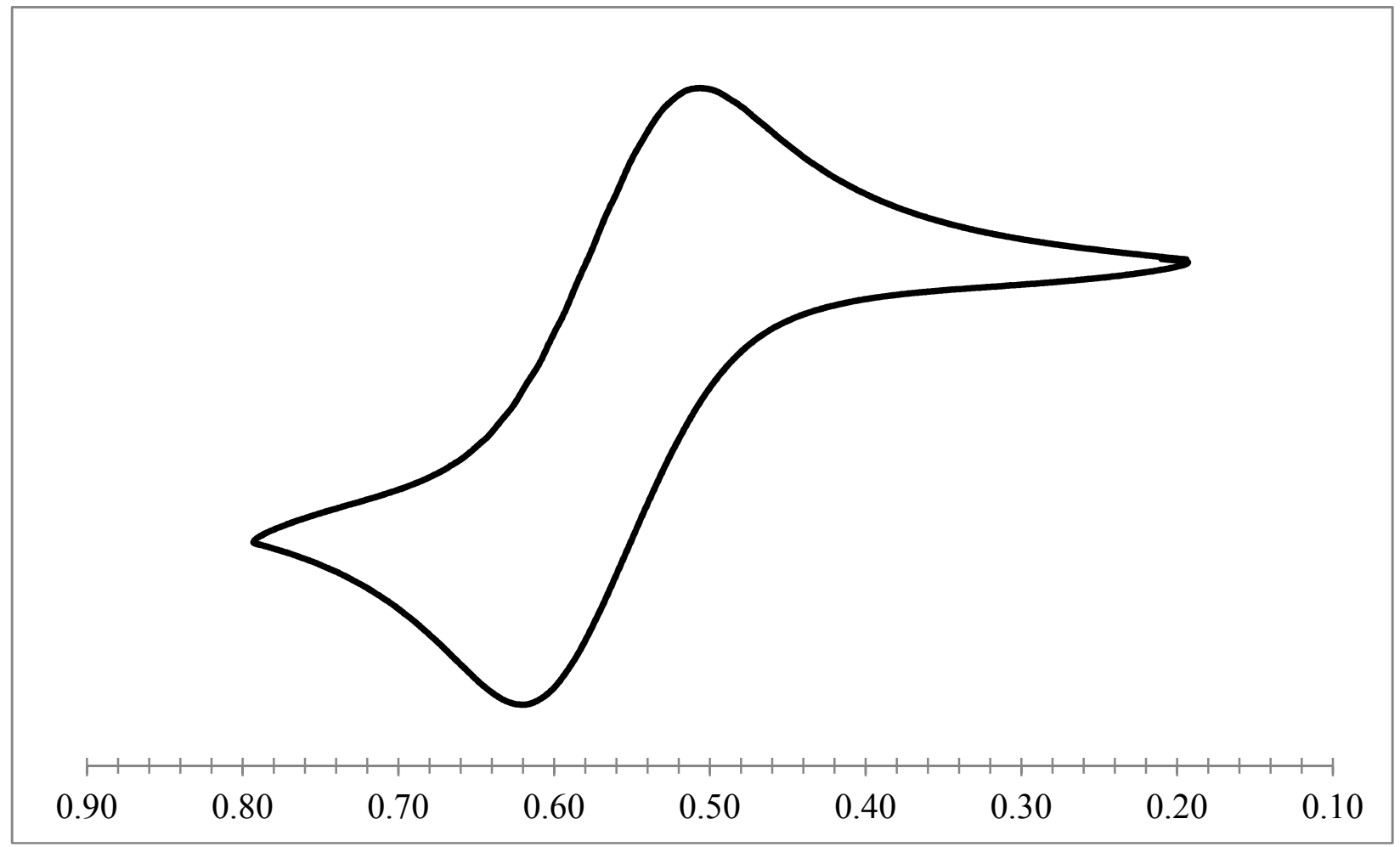

$1.0 \mathrm{mM} 1$ in DCM

$100 \mathrm{mM}\left[{ }^{\mathrm{n}} \mathrm{Bu}_{4} \mathrm{~N}\right]\left[\mathrm{PF}_{6}\right]$

Scan rate $100 \mathrm{mV} / \mathrm{s}$ )

$\mathrm{Ni}^{\mathrm{II}} / \mathrm{Ni}^{\mathrm{III}}:+0.57 \mathrm{~V}$ versus $\mathrm{Fc} / \mathrm{Fc}^{+}$

Potential (V) 
( ${ }^{\text {DIPP }}$ CCC)NiCl (1). ${ }^{1} \mathrm{H}$ NMR (400 MHz, THF- $\left.d_{8}\right) \delta 8.19(\mathrm{~d}, J=8.2 \mathrm{~Hz}, 2 \mathrm{H}, \mathrm{Ar}-\mathrm{C} H), 7.56(\mathrm{~d}, J$ $=7.8 \mathrm{~Hz}, 2 \mathrm{H}, \mathrm{Ar}-\mathrm{CH}), 7.46(\mathrm{t}, J=7.8 \mathrm{~Hz}, 2 \mathrm{H}, \mathrm{Ar}-\mathrm{CH}), 7.38-7.31$ (m, 3H, Ar-CH), 7.25 (t, $J=$ $7.7 \mathrm{~Hz}, 2 \mathrm{H}, \mathrm{Ar}-\mathrm{CH}), 7.16$ (d, $J=7.8 \mathrm{~Hz}, 4 \mathrm{H}, \mathrm{Ar}-\mathrm{CH}), 6.84(\mathrm{~d}, J=7.8 \mathrm{~Hz}, 2 \mathrm{H}, \mathrm{Ar}-\mathrm{C} H), 2.47$ (sept, $\left.J=6.8 \mathrm{~Hz}, 4 \mathrm{H},{ }^{\mathrm{i}} \operatorname{Pr}-\mathrm{CH}\right), 1.21\left(\mathrm{~d}, J=6.8 \mathrm{~Hz}, 12 \mathrm{H},{ }^{\mathrm{i}} \mathrm{Pr}-\mathrm{CH}_{3}\right), 0.88\left(\mathrm{~d}, J=6.8 \mathrm{~Hz}, 12 \mathrm{H},{ }^{\mathrm{i}} \operatorname{Pr}-\right.$ $\left.\mathrm{CH}_{3}\right)$.

Figure S2. ${ }^{1} \mathrm{H}$ NMR Spectrum of 1 in THF- $d_{8}(\delta 3.58,1.73)$

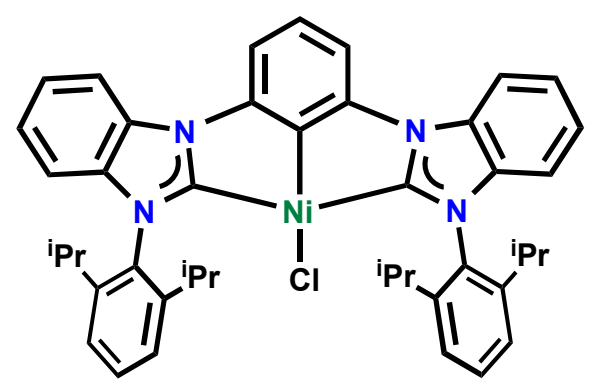

卢

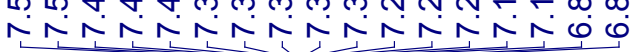
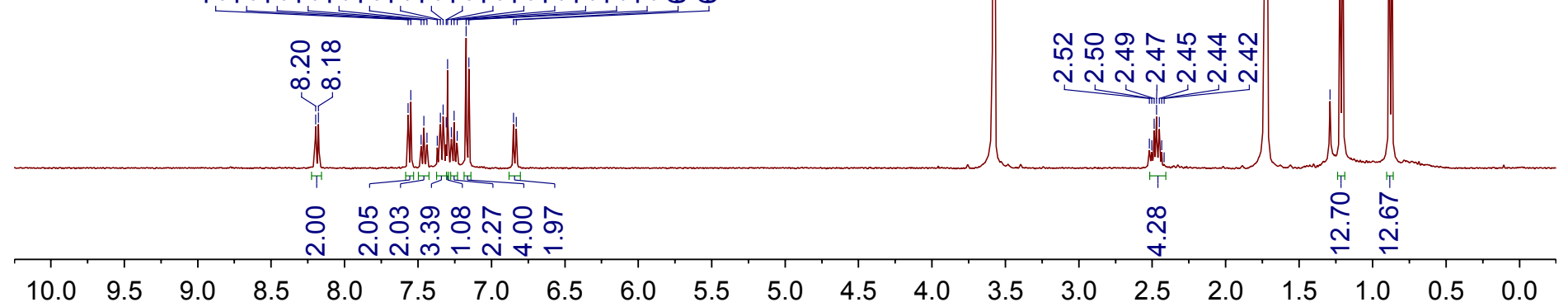


\section{Synthesis of $\left({ }^{\mathrm{DIPP}} \mathrm{CCC}\right) \mathrm{NiCl}_{3}(2)$}

A scintillation vial is charged with $\left({ }^{\mathrm{DIPP}} \mathrm{CCC}\right) \mathrm{NiCl}(25.0 \mathrm{mg}, 0.035 \mathrm{mmol}), \mathrm{PhICl}_{2}(9.7 \mathrm{mg}, 0.035$ $\mathrm{mmol})$, and a stir bar and cooled to $-35^{\circ} \mathrm{C}$. Approximately $2 \mathrm{~mL}$ of cold THF $\left(-35^{\circ} \mathrm{C}\right)$ is added, resulting in a color change from orange to purple. The reaction is stirred for 2 minutes after the addition of THF and subsequently solvents are removed in vacuo to afford a purple residue. To the residue, $5 \mathrm{~mL}$ of cold diethyl ether $\left(-35^{\circ} \mathrm{C}\right)$ is added and the resulting suspension is then filtered over a pad of Celite ${ }^{\mathrm{TM}}$ and washed with cold diethyl ether. The diethyl ether filtrate is discarded and the purple solid flushed with cold THF. Drying of the purple solution in vacuo furnishes ( $\left.{ }^{\mathrm{DIPP}} \mathrm{CCC}\right) \mathrm{NiCl}_{3}(20.9 \mathrm{mg}, 0.026 \mathrm{mmol}, 76 \%)$ as a purple solid. Crystals suitable for Xray diffraction were grown from vapor diffusion of pentane into a solution of 2 in benzene/THF at $\left(-35^{\circ} \mathrm{C}\right) .{ }^{1} \mathrm{H}$ NMR $\left(500 \mathrm{MHz}, \mathrm{THF}-d_{8}\right) \delta 8.42(\mathrm{~d}, J=8.1 \mathrm{~Hz}, 2 \mathrm{H}, \mathrm{Ar}-\mathrm{CH}), 7.96(\mathrm{~d}, J=7.8 \mathrm{~Hz}$, 2H, Ar-CH), 7.58 (t, $J=7.7 \mathrm{~Hz}, 2 \mathrm{H}, \mathrm{Ar}-\mathrm{CH}), 7.44-7.37$ (m, 5H, Ar-CH), 7.23 (d, J=7.7 Hz, 4H, Ar-CH), 7.06 (d, $J=8.1 \mathrm{~Hz}, 2 \mathrm{H}, \mathrm{Ar}-\mathrm{CH}), 2.80$ (sept, $\left.J=6.7 \mathrm{~Hz}, 4 \mathrm{H},{ }^{\mathrm{i}} \mathrm{Pr}-\mathrm{CH}\right), 1.14(\mathrm{~d}, J=$ 6.7 Hz, $\left.12 \mathrm{H},{ }^{\mathrm{i}} \mathrm{Pr}-\mathrm{CH}_{3}\right), 0.84\left(\mathrm{~d}, J=6.8 \mathrm{~Hz}, 12 \mathrm{H},{ }^{\mathrm{i}} \mathrm{Pr}-\mathrm{CH}_{3}\right)$. Thermal instability of 2 and reduced solubility at lower temperatures precluded characterization by ${ }^{13} \mathrm{C}$ NMR spectroscopy and CHN analysis. 
Figure S3. ${ }^{1} \mathrm{H}$ NMR Spectrum of 2 in THF- $d_{8}(\delta 3.58,1.73)$

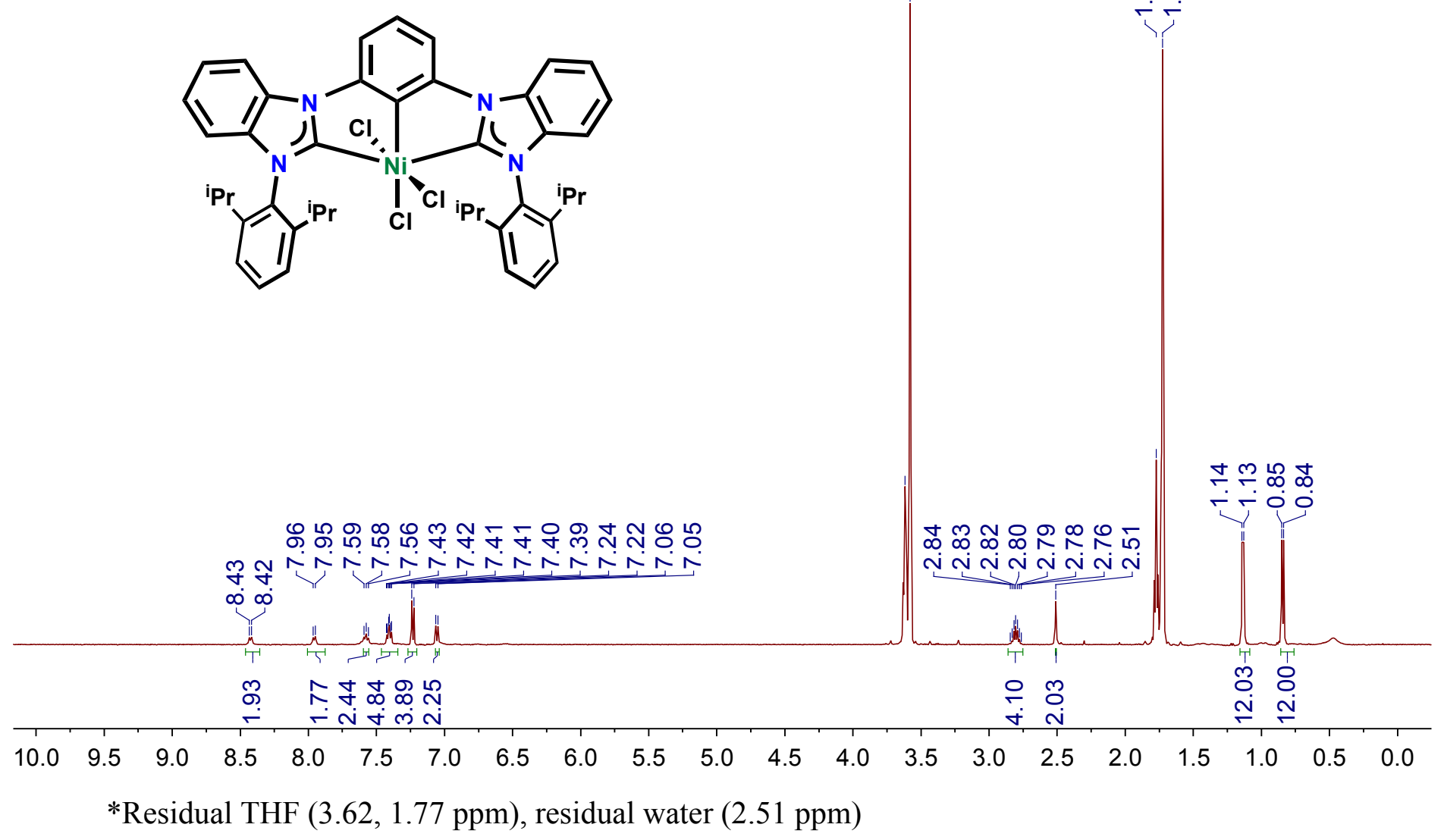

ชิ 
Figure S4. ${ }^{1} \mathrm{H}$ NMR Spectrum of reaction of 1 with $\mathrm{PhICl}_{2}$ in $\operatorname{THF}-d_{8}(\delta 3.58,1.73)$

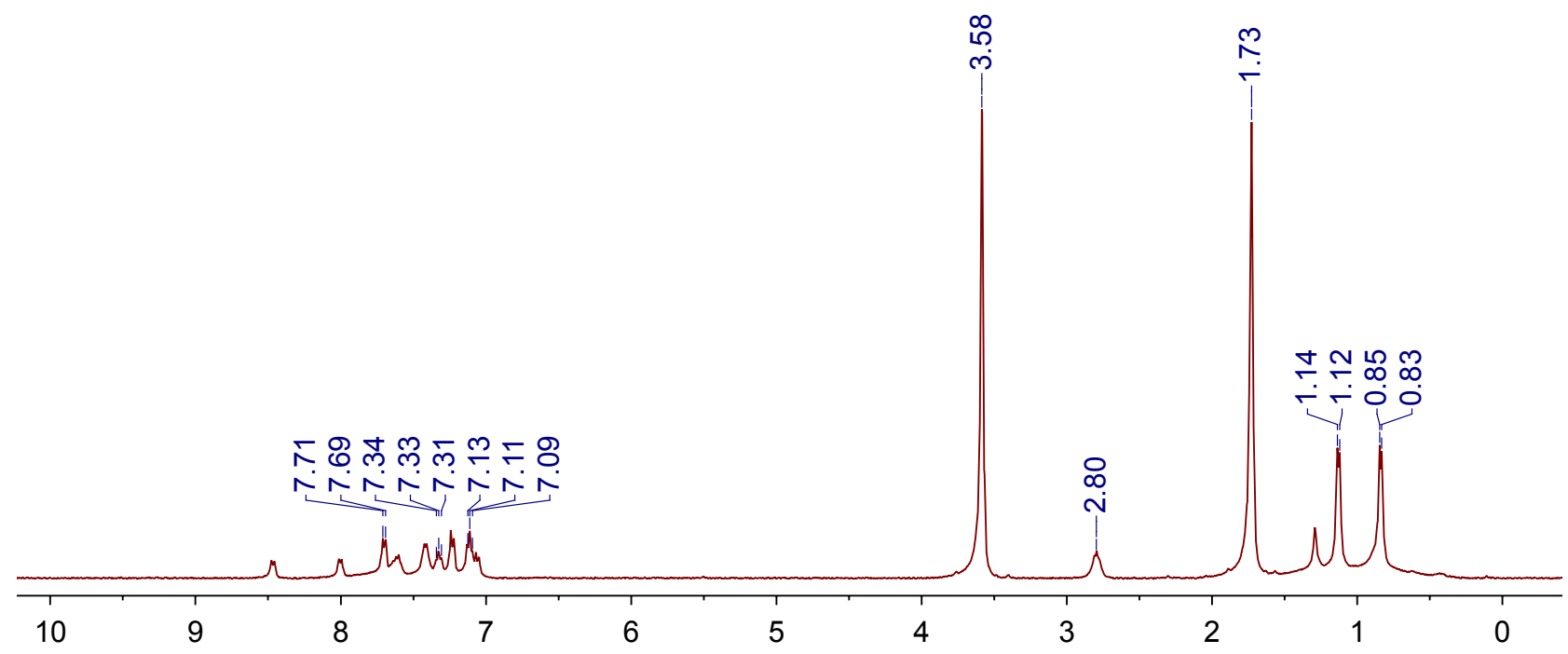

$* \mathrm{PhI}$

$7.70 \mathrm{ppm}, \mathrm{d}, 2 \mathrm{H}$

$7.33 \mathrm{ppm}, \mathrm{t}, 1 \mathrm{H}$

$7.11 \mathrm{ppm}, \mathrm{t}, 2 \mathrm{H}$ 
Figure S5. Bond lengths comparisons of $\mathbf{1}$ (black) and $\mathbf{2}$ (green)

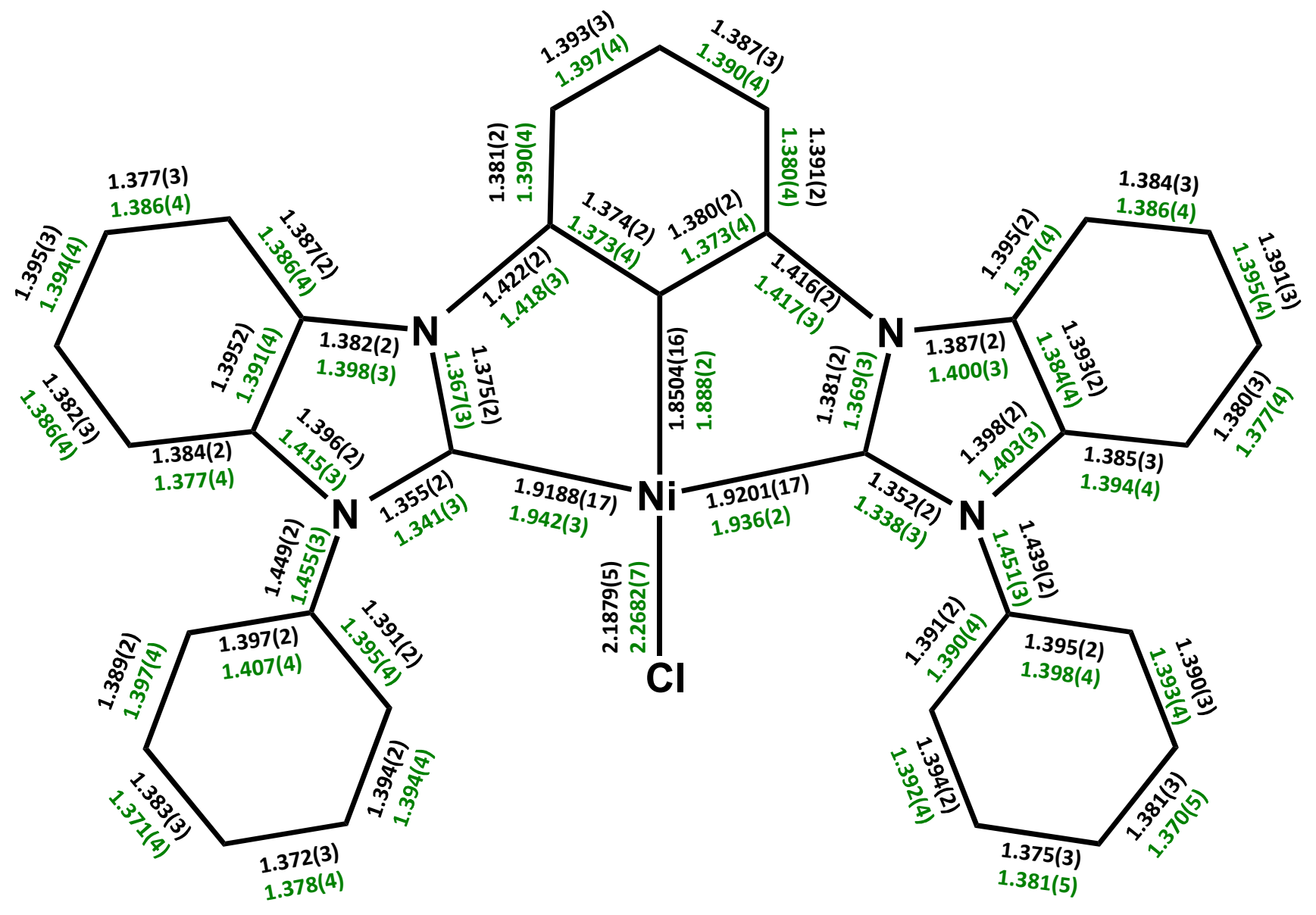




\section{Synthesis of $\left({ }^{\mathrm{DIPP}} \mathrm{CCC}\right) \mathrm{NiBr}(3)$}

A scintillation vial is charged with $\left({ }^{\mathrm{DIPP}} \mathrm{CCC}\right) \mathrm{NiCl}(50.0 \mathrm{mg}, 0.069 \mathrm{mmol})$, sodium thiophenolate (13.7 mg, $0.104 \mathrm{mmol}$ ), a stir bar, and approximately $7 \mathrm{~mL}$ of THF. A color change from orange to dark red is noted. The suspension is stirred for $15 \mathrm{~min}$ at room temperature and subsequently filtered over a pad of Celite ${ }^{\mathrm{TM}}$. Solvents are then removed under reduced pressure and the resulting solid residue is taken up in benzene and filtered over a pad of Celite ${ }^{\mathrm{TM}}$. The filtrate is concentrated under reduced pressure to afford $\left({ }^{\mathrm{DIPP}} \mathrm{CCC}\right) \mathrm{NiSPh}$. The solid is dissolved in approximately $6 \mathrm{~mL}$ of THF and $0.76 \mathrm{~mL}$ of aqueous $\mathrm{HBr}(0.1 \mathrm{M}, 0.076 \mathrm{mmol})$ is added dropwise. The resulting solution is transferred to a separatory funnel, followed by the addition of $25 \mathrm{~mL}$ of toluene and $20 \mathrm{~mL}$ of water. After shaking vigorously, the organic layer is collected and dried with anhydrous $\mathrm{Na}_{2} \mathrm{SO}_{4}$, then evaporated under reduced pressure. The resulting orange solid is washed with copious pentane over a pad of Celite ${ }^{\mathrm{TM}}$, subsequently flushed with THF and dried in vacuo to afford ( $\left.{ }^{\mathrm{DIPP}} \mathrm{CCC}\right) \mathrm{NiBr}(42.0 \mathrm{mg}, 0.047 \mathrm{mmol}, 79 \%)$ as an orange solid. Crystals suitable for X-ray diffraction were grown from vapor diffusion of diethyl ether into a solution of 3 in THF at room temperature. ${ }^{1} \mathrm{H}$ NMR $\left(400 \mathrm{MHz}, \mathrm{THF}-d_{8}\right) \delta 8.21(\mathrm{~d}, J=8.2 \mathrm{~Hz}, 2 \mathrm{H}, \mathrm{Ar}-\mathrm{C} H)$, 7.60 (d, $J=7.8 \mathrm{~Hz}, 2 \mathrm{H}, \mathrm{Ar}-\mathrm{CH}), 7.48$ (t, $J=7.7 \mathrm{~Hz}, 2 \mathrm{H}, \mathrm{Ar}-\mathrm{CH}), 7.41-7.32$ (m, 3H, Ar-CH), 7.27 (t, $J=7.6 \mathrm{~Hz}, 2 \mathrm{H}, \mathrm{Ar}-\mathrm{CH}), 7.17$ (d, $J=7.8 \mathrm{~Hz}, 4 \mathrm{H}, \mathrm{Ar}-\mathrm{C} H), 6.86$ (d, $J=8.1 \mathrm{~Hz}, 2 \mathrm{H}, \mathrm{Ar}-$ $\mathrm{CH}$ ), 2.46 (sept, $\left.J=6.9 \mathrm{~Hz}, 4 \mathrm{H},{ }^{\mathrm{i}} \operatorname{Pr}-\mathrm{CH}\right), 1.23$ (d, $\left.J=6.8 \mathrm{~Hz}, 12 \mathrm{H},{ }^{\mathrm{i}} \mathrm{Pr} \mathrm{C} H_{3}\right), 0.86(\mathrm{~d}, J=6.9 \mathrm{~Hz}$, 12H, $\left.{ }^{\mathrm{i}} \mathrm{Pr}-\mathrm{CH}_{3}\right) .{ }^{13} \mathrm{C}$ NMR $\left(101 \mathrm{MHz}\right.$, THF- $\left.d_{8}\right) \delta 185.71,150.97,148.11,146.13,138.89,133.99$, 130.14, 130.03, 125.71, 125.40, 124.25, 124.09, 112.96, 112.09, 109.16, 29.34, 24.61 23.87. Anal. Calcd for $\mathrm{C}_{44} \mathrm{H}_{45} \mathrm{~N}_{4} \mathrm{Ni}^{+}$: 687.2998. HR-MS (ESI ${ }^{+}$): 687.2977. 
Figure S6. ${ }^{1} \mathrm{H}$ NMR Spectrum of $\mathbf{3}$ in THF- $d_{8}(\delta 3.58,1.73)$

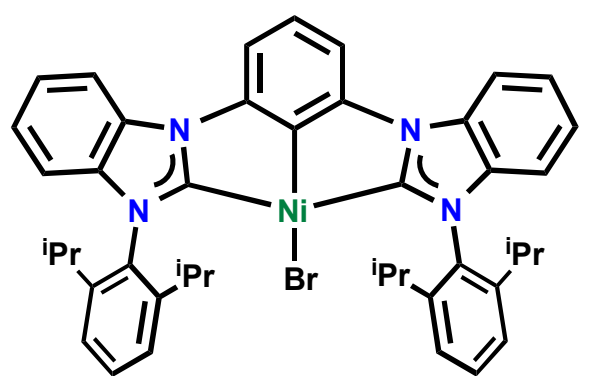

M워 $N$ N

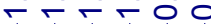

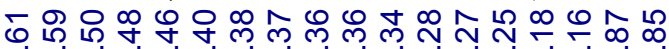

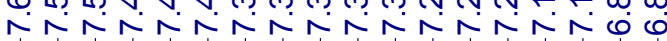

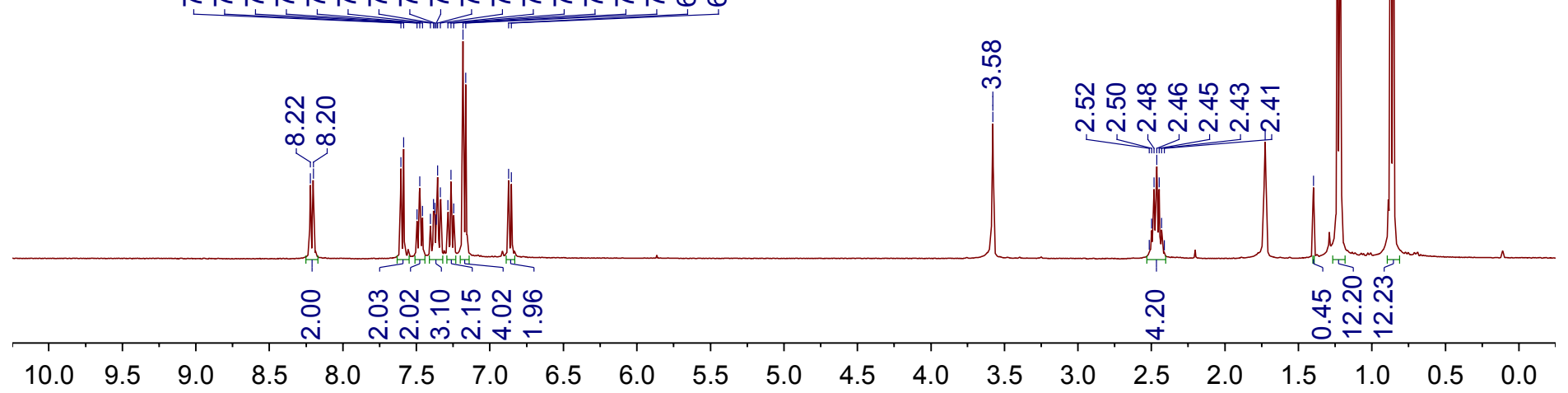

*Residual grease (1.40 ppm)

Figure S7. ${ }^{13} \mathrm{C}$ NMR Spectrum of 3 in THF- $d_{8}(\delta 67.21,25.13)$

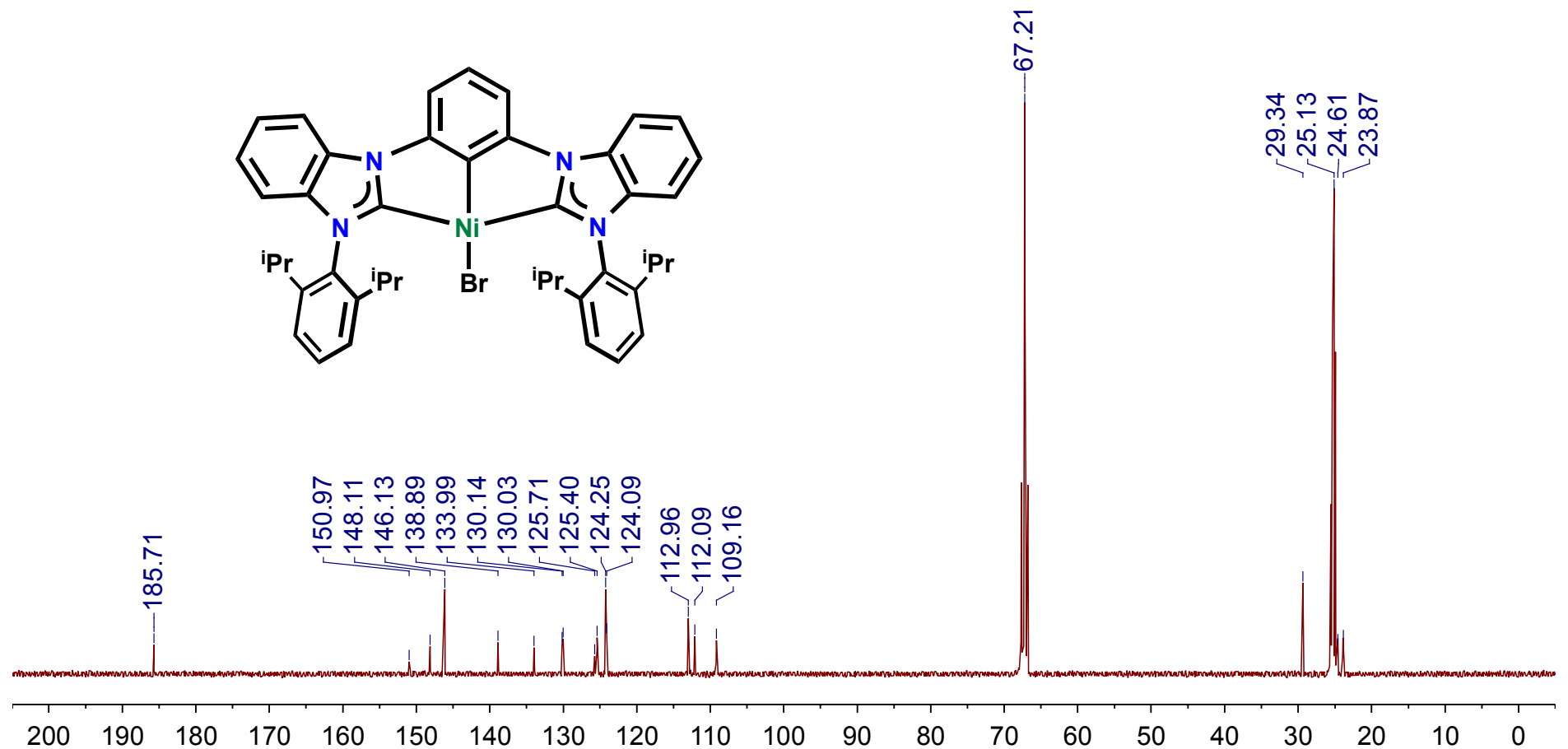


Figure S8. ${ }^{1} \mathrm{H}$ NMR Spectrum of $\mathbf{3}$ in benzene- $d_{6}(\delta 7.16)$

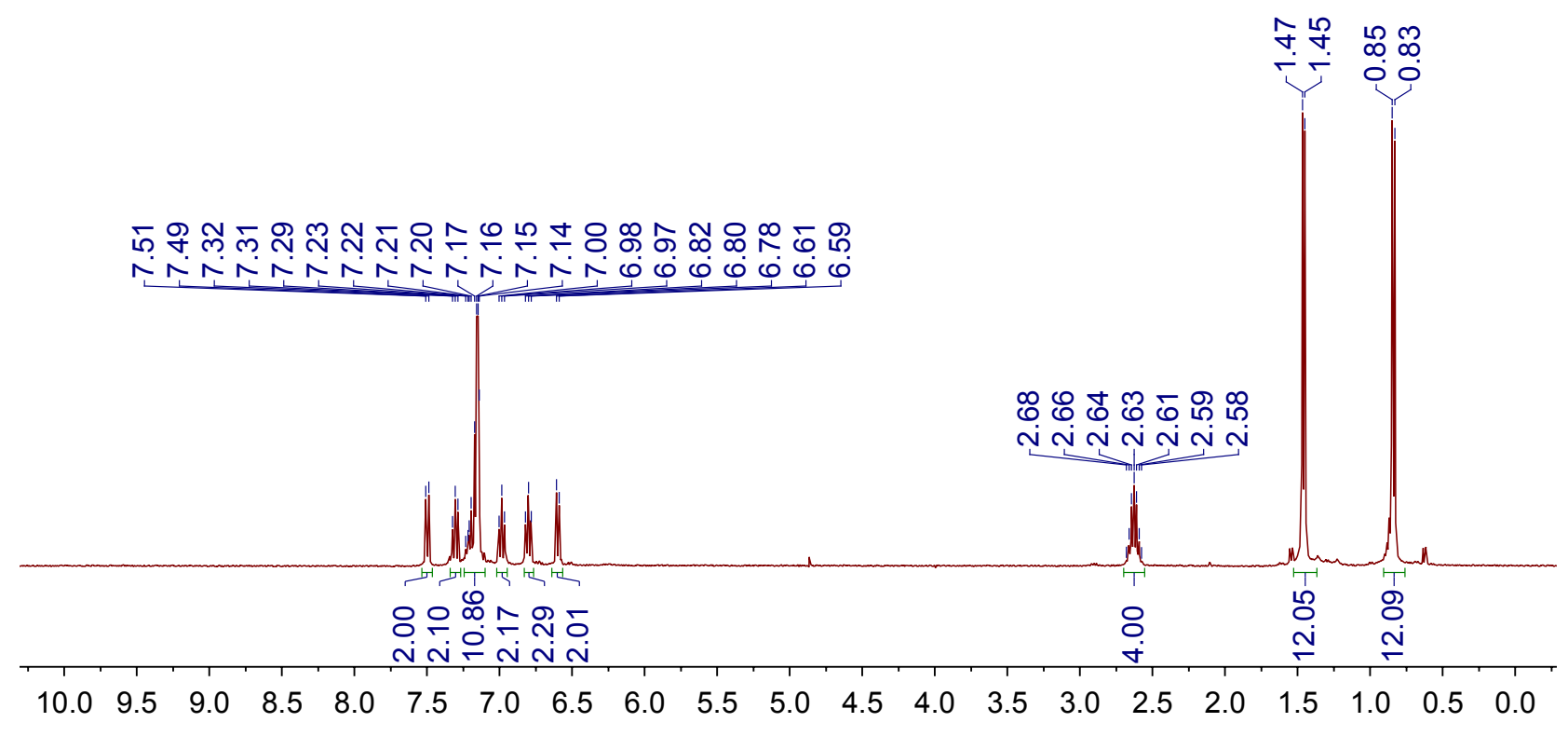




\section{Synthesis of $\left({ }^{\mathrm{DIPP}} \mathrm{CCC}\right) \mathrm{NiBr}_{3}(4)$}

Method A: Reaction of ( $\left.{ }^{\mathrm{DIPP}} \mathrm{CCC}\right) \mathrm{NiBr}(3)$ with bromine. A scintillation vial, $\left({ }^{\mathrm{DIPP}} \mathrm{CCC}\right) \mathrm{NiBr}$ ( $25.0 \mathrm{mg}, 0.033 \mathrm{mmol})$ is dissolved in approximately $3 \mathrm{~mL}$ of THF. A drop of $\mathrm{Br}_{2}(\sim 10 \mathrm{mg}$, $0.063 \mathrm{mmol}$ ) is then added to the orange solution, resulting in an immediate color change to dark green. The resulting solution was stirred at room temperature for $5 \mathrm{~min}$ and then the solvent was removed under reduced pressure to afford a dark green residue. The green residue is triturated with pentane, filtered over a pad of Celite ${ }^{\mathrm{TM}}$, and washed with copious pentane to ensure removal of excess bromine. The remaining solid is then flushed with THF and dried in vacuo to afford ( $\left.{ }^{\mathrm{DIPP}} \mathrm{CCC}\right) \mathrm{NiBr}_{3}(29.3 \mathrm{mg}, 0.0316 \mathrm{mmol}, 97 \%)$ as a dark green solid.

\section{Method B: Reaction of $\left({ }^{\mathrm{DIPP}} \mathrm{CCC}\right) \mathrm{NiBr}(3)$ with $\mathrm{BTMABr}_{3}$.}

A scintillation vial is charged with $\left({ }^{\mathrm{DIPP}} \mathrm{CCC}\right) \mathrm{NiBr}(25.0 \mathrm{mg}, 0.033 \mathrm{mmol}), \mathrm{BTMABr}_{3}(13.0 \mathrm{mg}$, $0.033 \mathrm{mmol}$ ), and approximately $1.5 \mathrm{~mL}$ of THF. The resulting dark green solution is stirred for 5 minutes at room temperature. The green solution is filtered through a Pasteur pipette packed with silica to remove the benzyltrimethylammonium bromide byproduct, using THF as the eluent. The filtrate is dried in vacuo to furnish $\left({ }^{\mathrm{DIPP}} \mathrm{CCC}\right) \mathrm{NiBr}_{3}(29.0 \mathrm{mg}, 31.2 \mathrm{mmol}, 96 \%)$ as a dark green solid.

Crystals suitable for X-ray diffraction were grown from slow evaporation of a solution of $\mathbf{4}$ in benzene at room temperature. ${ }^{1} \mathrm{H}$ NMR $\left(400 \mathrm{MHz}, \mathrm{THF}-d_{8}\right) \delta 8.51(\mathrm{~d}, J=8.3 \mathrm{~Hz}, 2 \mathrm{H}, \mathrm{Ar}-\mathrm{CH})$, $8.12(\mathrm{~d}, J=7.9 \mathrm{~Hz}, 2 \mathrm{H}, \mathrm{Ar}-\mathrm{CH}), 7.61(\mathrm{t}, J=7.7 \mathrm{~Hz}, 2 \mathrm{H}, \mathrm{Ar}-\mathrm{C} H), 7.51$ (t, $J=7.9 \mathrm{~Hz}, 1 \mathrm{H}, \mathrm{Ar}-$ $\mathrm{CH}), 7.43$ (t, $J=7.4 \mathrm{~Hz}, 4 \mathrm{H}, \mathrm{Ar}-\mathrm{CH}), 7.25$ (d, $J=7.8 \mathrm{~Hz}, 4 \mathrm{H}, \mathrm{Ar}-\mathrm{CH}), 7.07$ (d, $J=8.2 \mathrm{~Hz}, 2 \mathrm{H}$, Ar-CH), 2.98 (sept, $J=6.5 \mathrm{~Hz}, 4 \mathrm{H},{ }^{\mathrm{i}} \operatorname{Pr}-\mathrm{C} H$ ), 1.19 (d, $\left.J=6.6 \mathrm{~Hz}, 12 \mathrm{H},{ }^{\mathrm{i}} \operatorname{Pr}-\mathrm{CH}_{3}\right), 0.85$ (d, $J=6.8$ $\left.\mathrm{Hz}, 12 \mathrm{H},{ }^{\mathrm{i}} \mathrm{Pr}-\mathrm{CH}_{3}\right) .{ }^{13} \mathrm{C} \mathrm{NMR}\left(126 \mathrm{MHz}, \mathrm{THF}-d_{8}\right) \delta 179.93,149.32,147.59,143.67,138.89$, 132.87, 132.13, 130.58, 127.40, 125.96, 124.97, 124.60, 114.50, 113.37, 113.34, 29.19, 25.65, 24.18. Anal. Calcd for $\mathrm{C}_{44} \mathrm{H}_{45} \mathrm{~N}_{4} \mathrm{NiBr}_{3}$ : C, 56.93; H, 4.89; N, 6.04. Found: C, 57.28; H, 4.84; N, 6.01 . 
Figure S9. ${ }^{1} \mathrm{H}$ NMR Spectrum of 4 in THF- $d_{8}(\delta 3.58,1.73)$

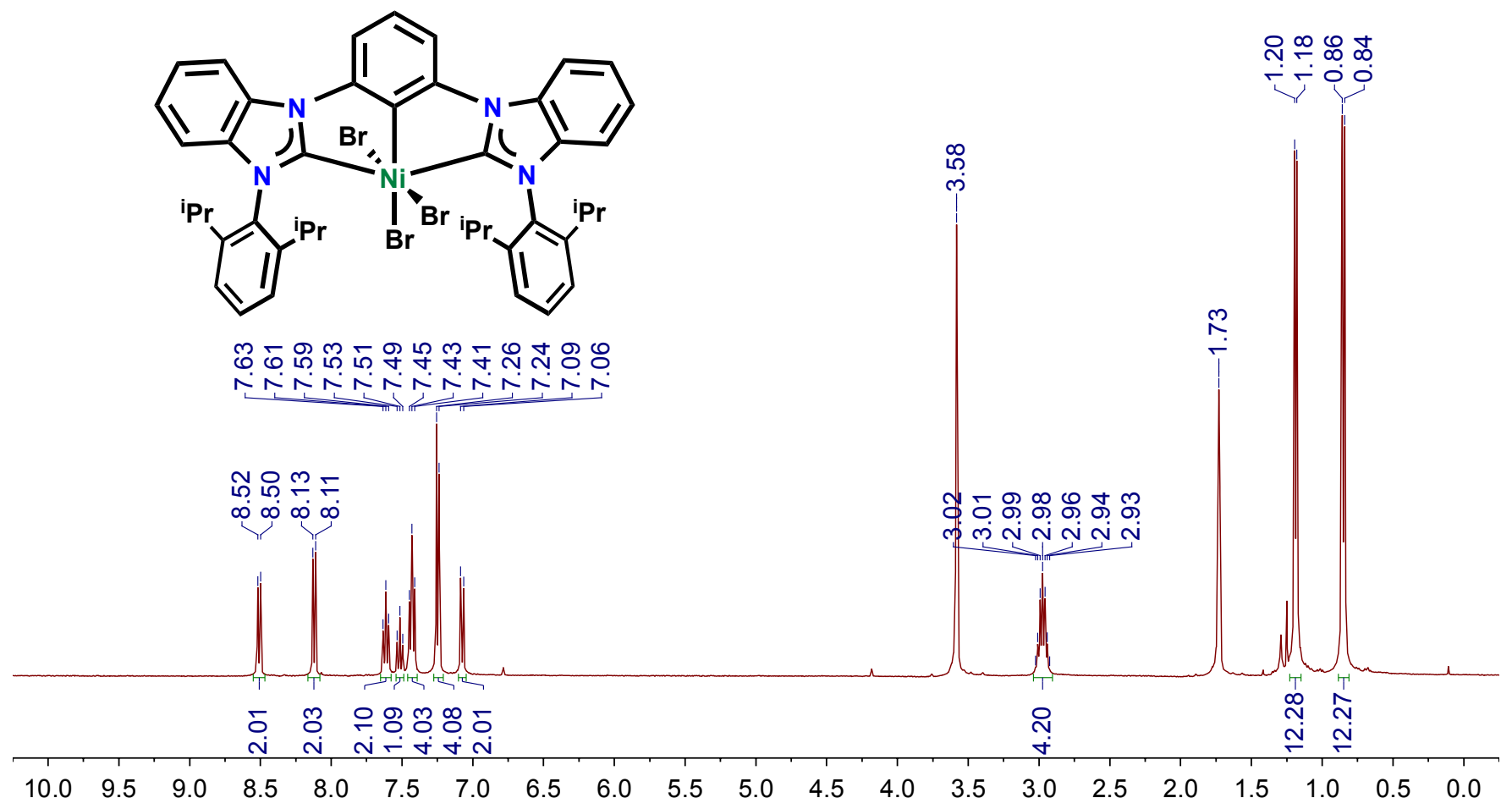

Figure S10. ${ }^{13} \mathrm{C}$ NMR Spectrum of 4 in THF- $d_{8}(\delta 67.21,21.14)$

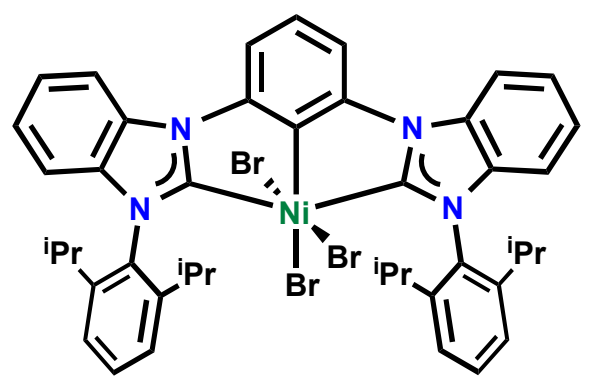

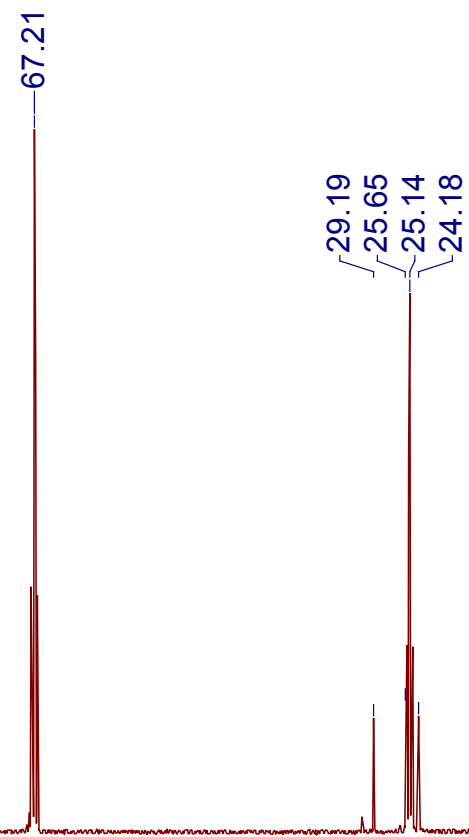

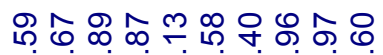

守守嵒
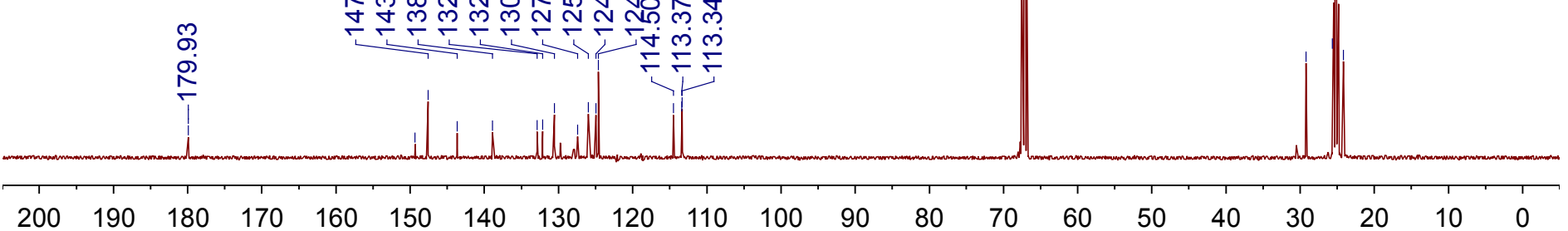
Figure S11. ${ }^{1} \mathrm{H}$ NMR Spectrum of 4 in benzene- $d_{6}(\delta 7.16)$

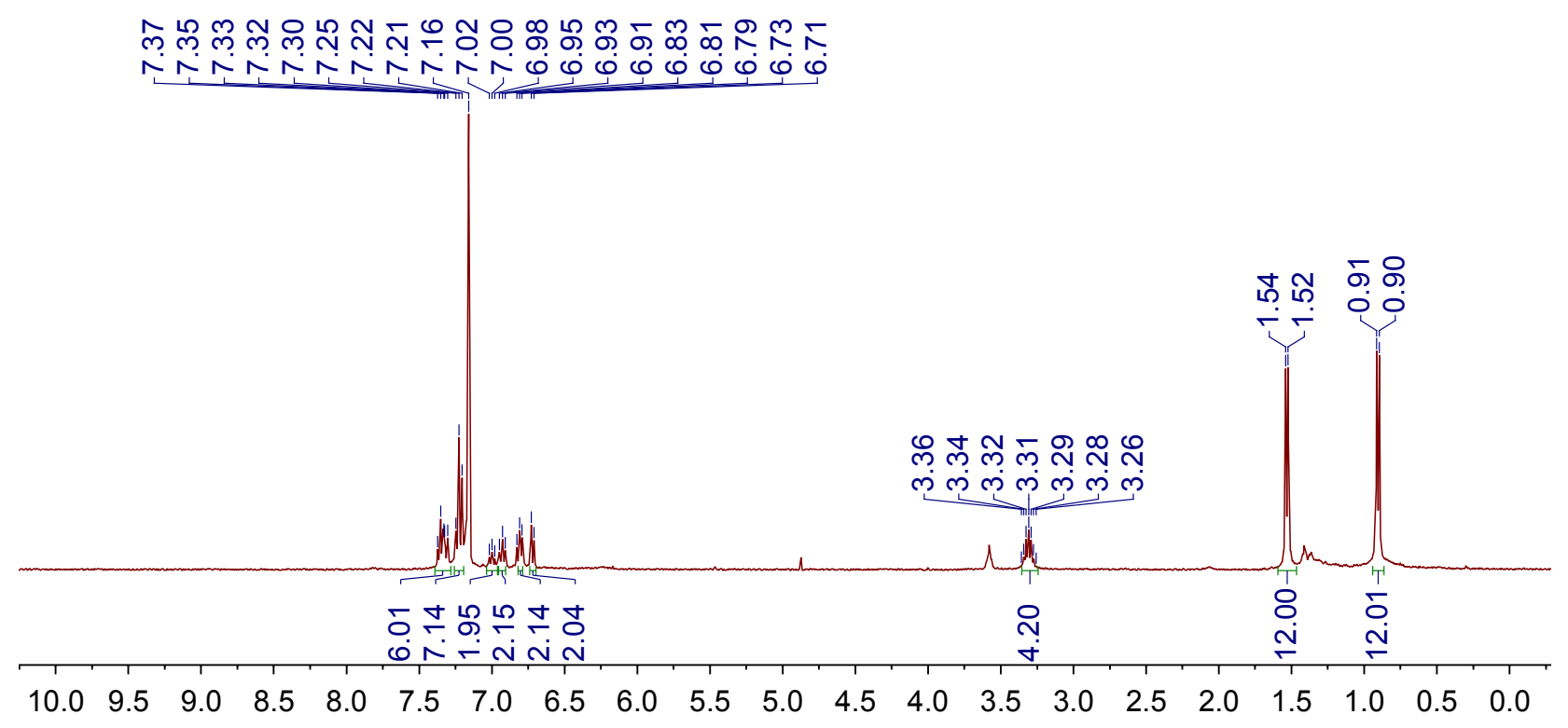


Figure S12. Bond lengths comparisons of 3 (black) and $\mathbf{4}$ (green)

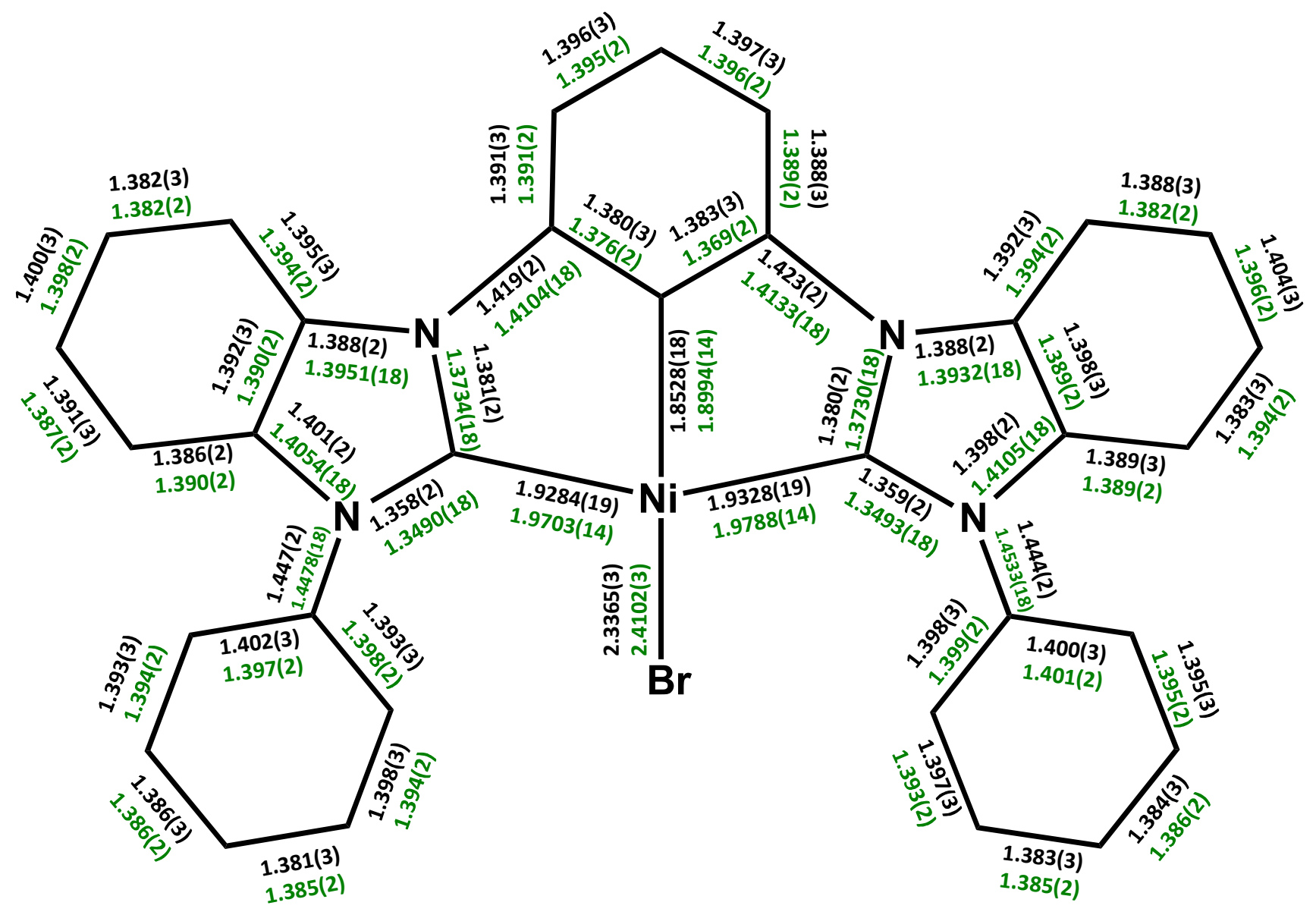


Figure S13. ${ }^{1} \mathrm{H}$ NMR Spectrum of 4 in THF- $d_{8}(\delta 3.58,1.73)$ after 6 hours at $50^{\circ} \mathrm{C}$

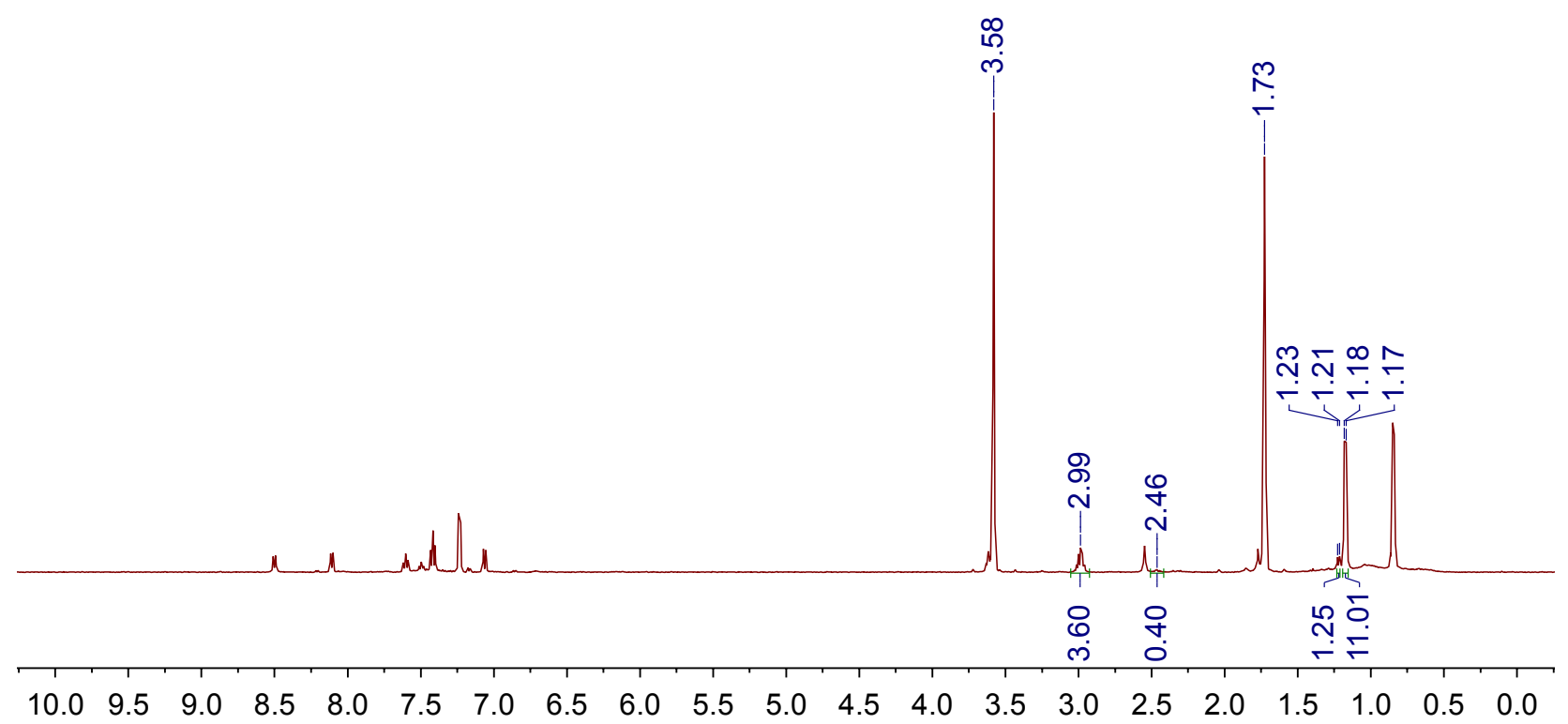

Figure S14. ${ }^{1} \mathrm{H}$ NMR Spectrum of 4 in THF- $d_{8}(\delta 3.58,1.73)$ after 24 hours at $50^{\circ} \mathrm{C}$

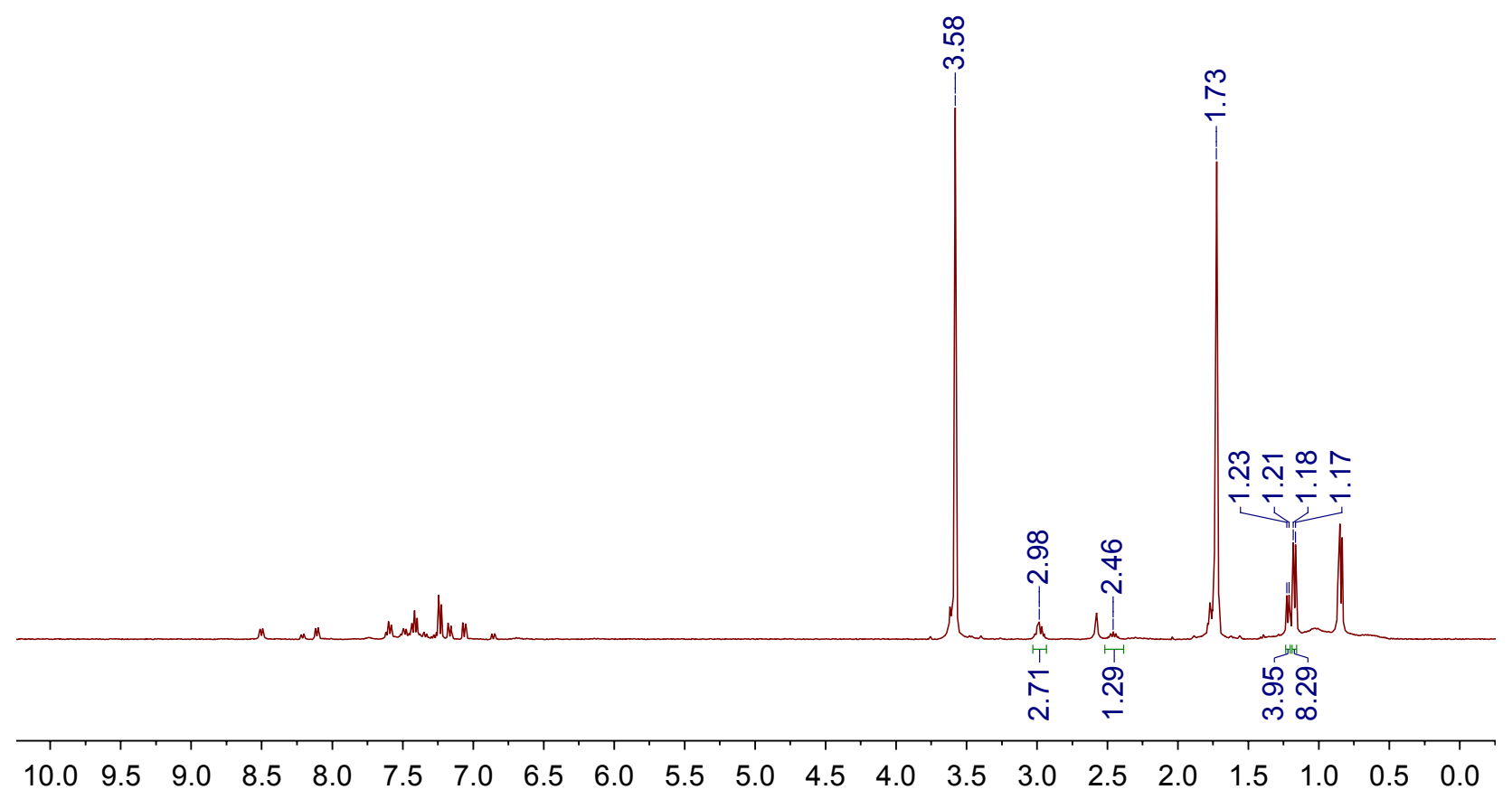




\section{Information for Table 2.}

\section{Reaction of 4 with styrene and cyclohexene.}

A $20 \mathrm{~mL}$ scintillation vial was charged with complex $4(7.5 \mathrm{mg}, 0.0081 \mathrm{mmol})$, substrate $(84.1$ $\mathrm{mg}$ styrene or $66.4 \mathrm{mg}$ cyclohexene) $(0.81 \mathrm{mmol})$, a stir bar, and approximately $2 \mathrm{~mL}$ of THF. [4] $=0.04 \mathrm{M}$, [susbtrate] $=0.40 \mathrm{M}$. The reaction was stirred at room temperature for $24 \mathrm{~h}$, volatiles were removed under reduced pressure, and durene was added as an internal standard before taking the ${ }^{1} \mathrm{H}$ NMR spectrum in THF- $d_{8}$. An aliquot of the reaction was analyzed by GCMS to determine the products of the reaction. The reaction with cyclohexene was also run in THF- $d_{8}$ for quantification of 1,2-dibromocyclohexane (no removal of volatiles in vacuo). The products were confirmed by matching ${ }^{1} \mathrm{H}$ NMR spectra and retention times of independently prepared samples of (1,2-dibromoethyl)benzene and 1,2-dibromocyclohexane.

Figure S15. ${ }^{1} \mathrm{H}$ NMR Spectrum of reaction 4 with styrene in THF- $d_{8}(\delta 3.58,1.73)$

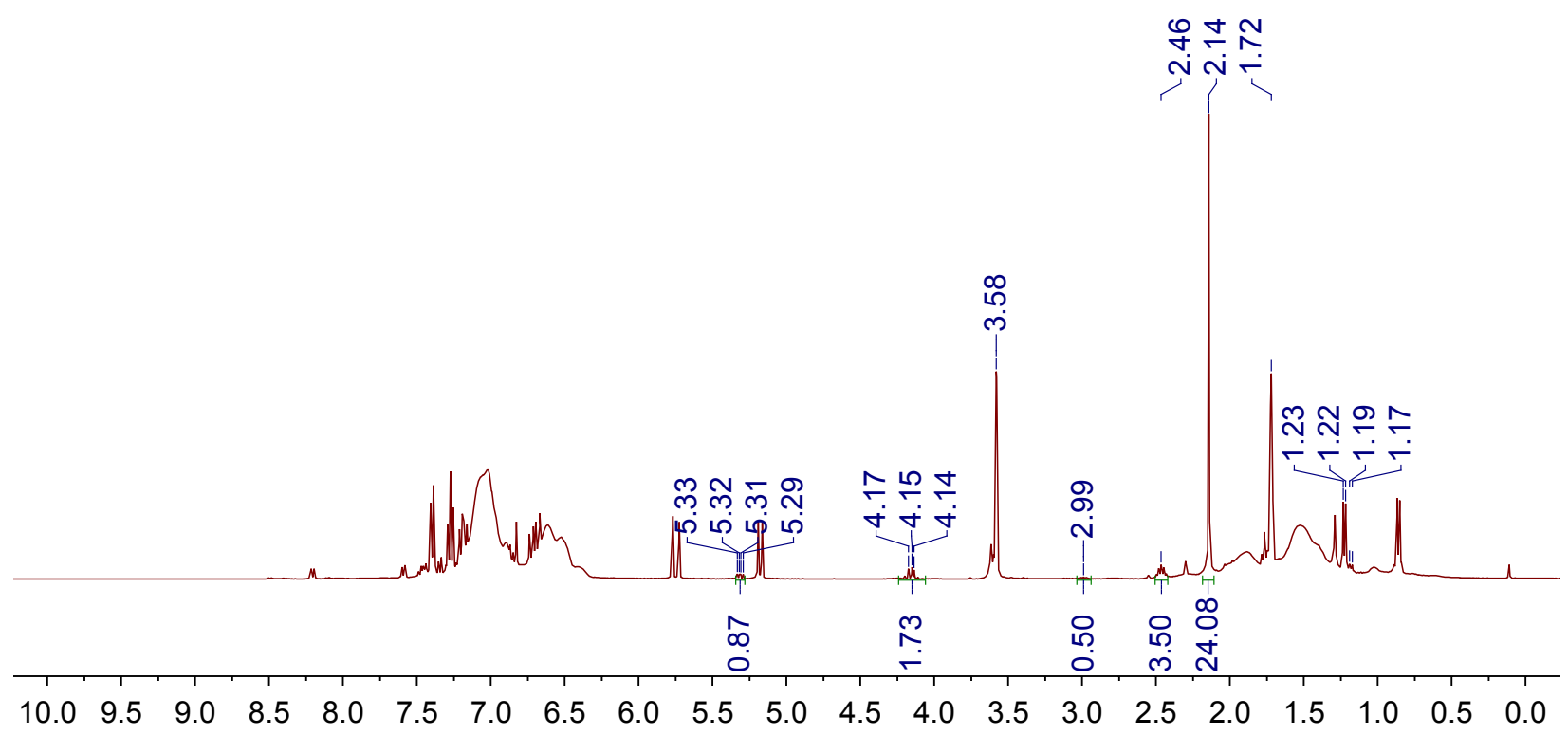

(1,2-dibromoethyl)benzene: $5.31 \mathrm{ppm}, 1 \mathrm{H} ; 4.15 \mathrm{ppm}, 2 \mathrm{H}$

durene standard: 2.14 ppm 
Figure S16. ${ }^{1} \mathrm{H}$ NMR Spectrum of reaction 4 with cyclohexene in $\operatorname{THF}-d_{8}(\delta 3.58,1.73)$

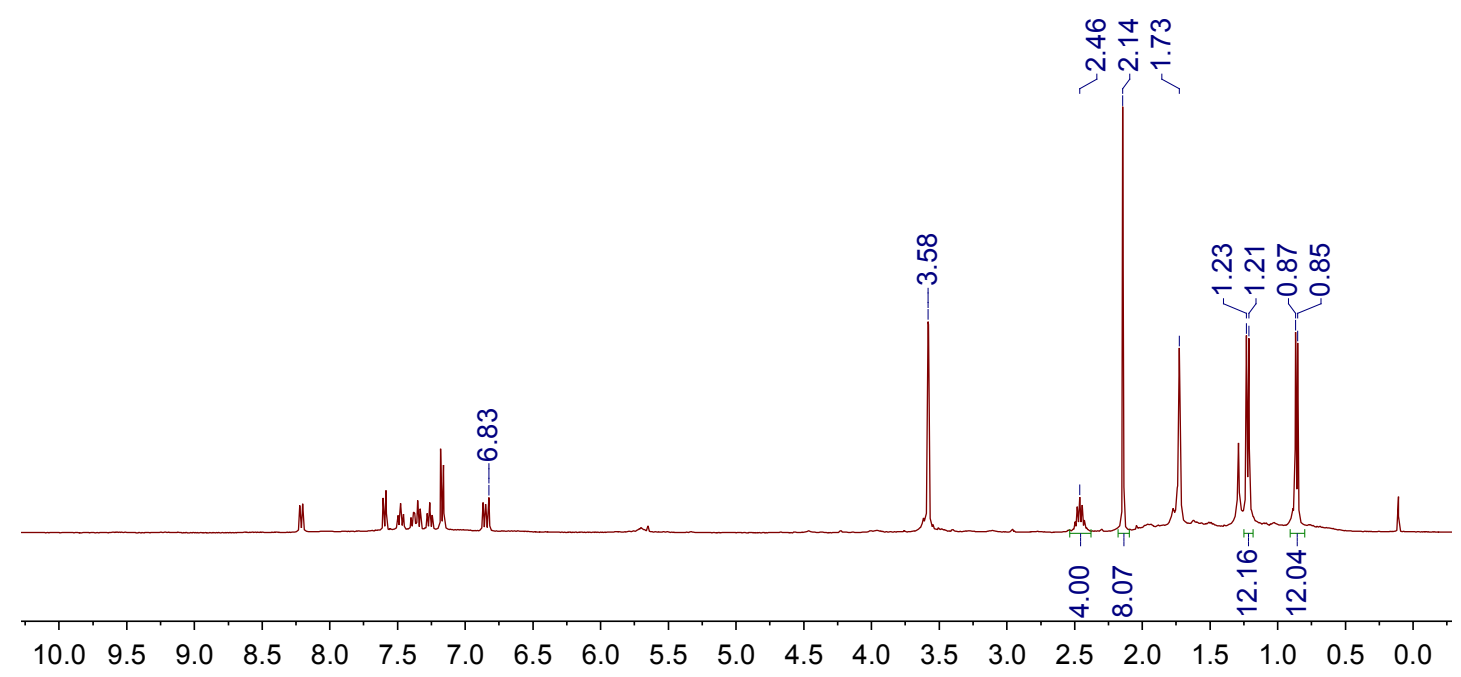

durene standard: $6.38,2.14 \mathrm{ppm}$

Figure S17. ${ }^{1} \mathrm{H}$ NMR Spectrum of reaction 4 with cyclohexene in $\mathrm{THF}-d_{8}(\delta 3.58,1.73)$

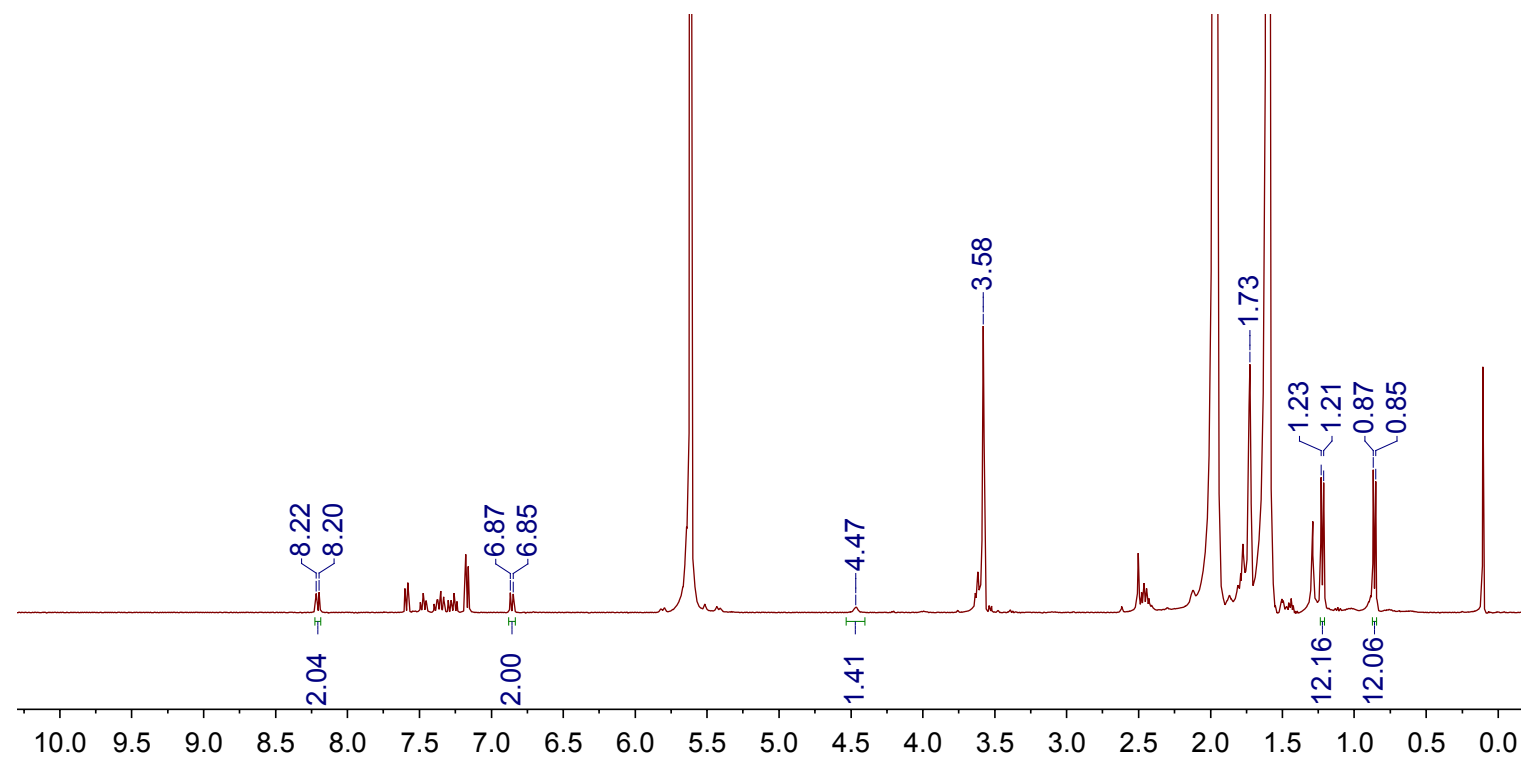

1,2-dibromocyclohexane: $4.47 \mathrm{ppm}, 2 \mathrm{H}$

cyclohexene: $5.62 \mathrm{ppm}, 1.97 \mathrm{ppm}, 1.60 \mathrm{ppm}$ 


\section{Reaction of 4 with 2-mesitylmagnesium bromide and lithium hexamethyldisilazide}

A $20 \mathrm{~mL}$ scintillation vial was charged with complex $4(5.0 \mathrm{mg}, 0.0054 \mathrm{mmol})$, substrate $(5.5 \mu \mathrm{L}$ 2-mesitylmagnesium bromide 1.0 M in THF or $\left.0.9 \mathrm{mg} \mathrm{TMS} \mathrm{TL}_{2} \mathrm{NLi}\right)(0.0054 \mathrm{mmol})$, a stir bar and approximately $0.6 \mathrm{~mL}$ of benzene- $d_{6}$. A color change to orange was immediately noted. The ${ }^{1} \mathrm{H}$ NMR spectra of the reactions were recorded. In addition, the reactions were analyzed by GC-MS to determine the products of the reaction.

Figure S18. ${ }^{1} \mathrm{H}$ NMR Spectrum of reaction 4 with 2-mesitylmagnesium bromide (1 eq.) in benzene- $d_{6}(\delta 7.16)$

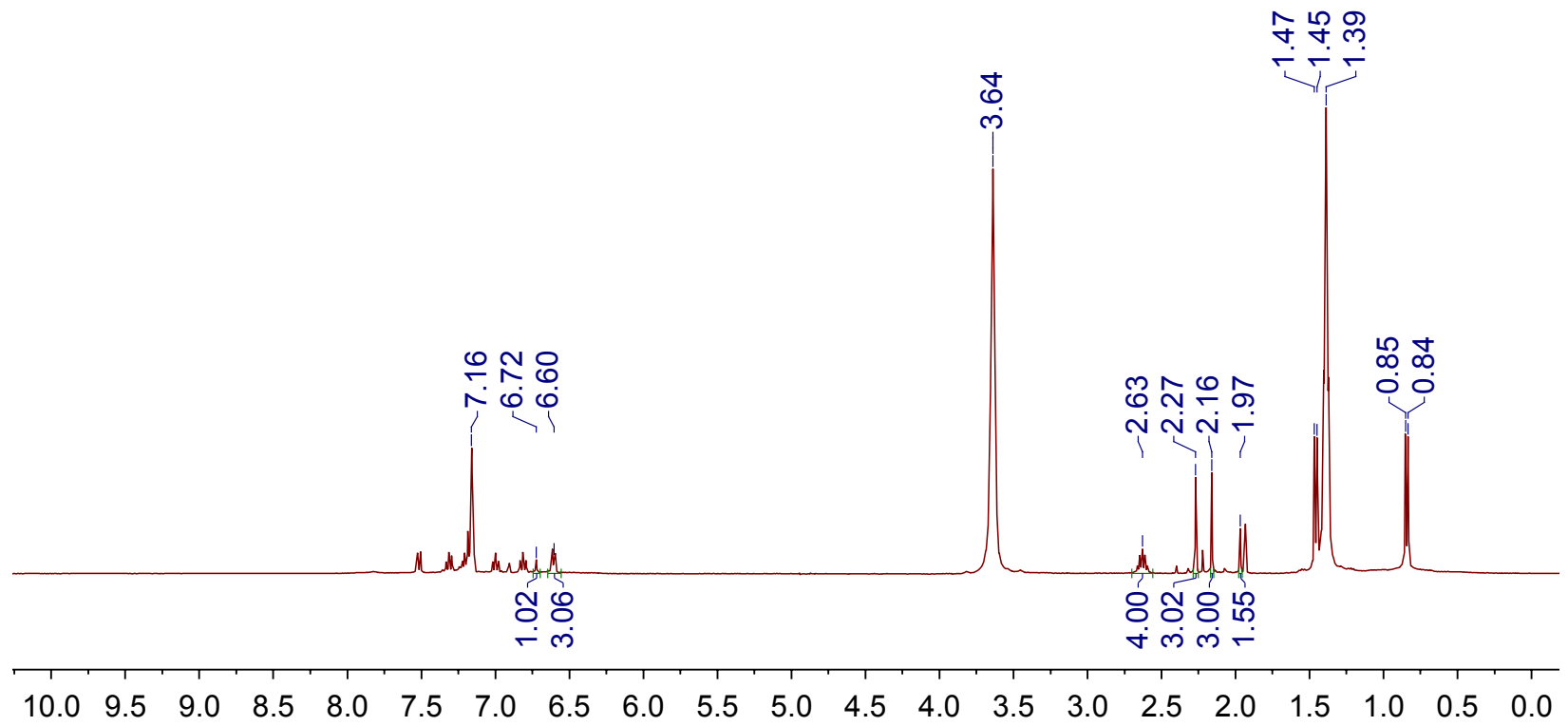

2-bromomesitylene: 6.60 ppm, 2H; 2.27 ppm, 6H; 1.97 ppm, 3H

mesitylene: $6.72 \mathrm{ppm}, 3 \mathrm{H} ; 2.16 \mathrm{ppm}, 9 \mathrm{H}$.

THF residual solvent: $3.64,1.39$ ppm 
Figure S19. ${ }^{1} \mathrm{H}$ NMR Spectrum of reaction 4 with $\mathrm{TMS}_{2} \mathrm{NLi}(1$ eq. $)$ in benzene- $d_{6}(\delta 7.16)$

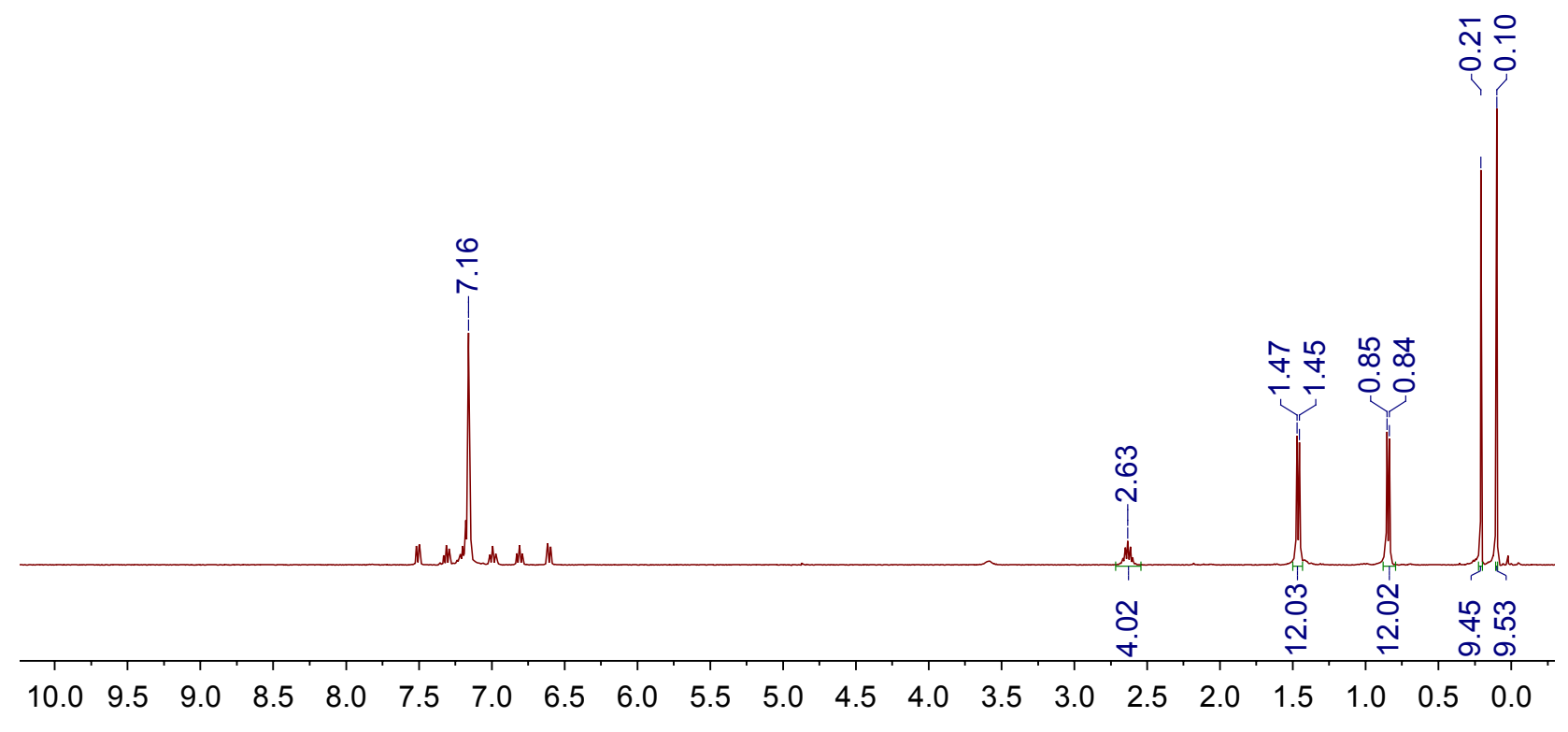

$\mathrm{TMS}_{2} \mathrm{NBr}: 0.21 \mathrm{ppm}, 18 \mathrm{H}$

$\mathrm{TMS}_{2} \mathrm{NH}: 0.10 \mathrm{ppm}, 18 \mathrm{H}$ 
Table S1. Crystallographic parameters for complexes 2-4

\begin{tabular}{|c|c|c|c|}
\hline & $\left({ }^{\mathrm{DIPP}} \mathrm{CCC}\right) \mathrm{NiCl}_{3}(2)$ & $\left({ }^{\mathrm{DIPP}} \mathrm{CCC}\right) \mathrm{NiBr}(3)$ & $\left({ }^{\mathrm{DIPP}} \mathrm{CCC}\right) \mathrm{NiBr}_{3}(4)$ \\
\hline Empirical formula & $\mathrm{C}_{59.8} \mathrm{H}_{66.2} \mathrm{Cl}_{3} \mathrm{~N}_{4} \mathrm{NiO}$ & $\mathrm{C}_{44} \mathrm{H}_{45} \mathrm{~N}_{4} \mathrm{NiBr}$ & $\mathrm{C}_{44} \mathrm{H}_{45} \mathrm{Br}_{3} \mathrm{~N}_{4} \mathrm{Ni}$ \\
\hline Formula weight & 1022.06 & 768.46 & 928.28 \\
\hline Temperature (K) & 100 & 100 & 100 \\
\hline Wavelength (Å) & 0.71073 & 0.71073 & 0.71073 \\
\hline Crystal system & tetragonal & triclinic & monoclinic \\
\hline Space group & $\mathrm{I} 4_{1} / \mathrm{a}$ & $\mathrm{P}-1$ & $\mathrm{P} 2_{1} / \mathrm{n}$ \\
\hline \multicolumn{4}{|l|}{ Unit Cell Dimentions } \\
\hline a $(\AA)$ & $26.8014(17)$ & $8.6747(4)$ & $13.3193(16)$ \\
\hline b $(\AA)$ & $26.8014(17)$ & $13.9513(7)$ & $18.921(2)$ \\
\hline c (Å) & $30.1916(19)$ & $16.8043(8)$ & $15.6120(19)$ \\
\hline$\alpha\left({ }^{\circ}\right)$ & 90 & $111.4611(18)$ & 90 \\
\hline$\beta\left({ }^{\circ}\right)$ & 90 & $101.546(2)$ & $90.851(6)$ \\
\hline$\gamma\left({ }^{\circ}\right)$ & 90 & $97.071(2)$ & 90 \\
\hline Volume $\left(\AA^{\mathbf{3}}\right)$ & $21687(3)$ & $1810.91(15)$ & $3934.1(8)$ \\
\hline $\mathbf{Z}$ & 16 & 2 & 4 \\
\hline Reflections collected & 183569 & 73617 & 135259 \\
\hline $\begin{array}{l}\text { Independent } \\
\text { reflections }\end{array}$ & $9982\left[\mathrm{R}_{\mathrm{int}}=0.0879\right]$ & $8022\left[\mathrm{R}_{\mathrm{int}}=0.0442\right]$ & $9822\left[\mathrm{R}_{\mathrm{int}}=0.0406\right]$ \\
\hline Goodness-of-fit on $F^{2}$ & 1.056 & 1.098 & 1.062 \\
\hline $\begin{array}{l}\text { Final } R \text { indexes } \\
{[I>=2 \sigma(I)]}\end{array}$ & $\begin{array}{c}\mathrm{R}_{1}=0.0432 \\
\mathrm{wR}_{2}=0.1180\end{array}$ & $\begin{array}{c}\mathrm{R}_{1}=0.0299 \\
\mathrm{wR}_{2}=0.0689\end{array}$ & $\begin{array}{c}\mathrm{R}_{1}=0.0200 \\
\mathrm{wR}_{2}=0.0509\end{array}$ \\
\hline $\begin{array}{l}\text { Final } R \text { indexes } \\
\text { [all data] }\end{array}$ & $\begin{array}{c}\mathrm{R}_{1}=0.0627 \\
\mathrm{wR}_{2}=0.1256\end{array}$ & $\begin{array}{c}\mathrm{R}_{1}=0.0370 \\
\mathrm{wR}_{2}=0.0725\end{array}$ & $\begin{array}{c}\mathrm{R}_{1}=0.0249 \\
\mathrm{wR}_{2}=0.0524\end{array}$ \\
\hline
\end{tabular}




\section{References}

(1) Pangborn, A. B.; Giardello, M. A.; Grubbs, R. H.; Rosen, R. K.; Timmers, F. J. Organometallics 1996, 15, 1518-1520.

(2) Matson, E. M.; Espinosa Martinez, G.; Ibrahim, A. D.; Jackson, B. J.; Bertke, J. A.; Fout, A. R. Organometallics 2015, 34, 399-407.

(3) Zhao, X.-F.; Zhang, C. Synthesis 2007, 2007, 551-557.

(4) Berthelot, J.; Benammar, Y.; Lange, C. Tetrahedron Lett. 1991, 32, 4135-4136. 